\title{
Carbon-14 Production in Fusion Reactors
}

R. D. Scheele

L. L. Burger

September 1976

Prepared for the Energy Research and Development Administration under Contract E(45-1)-1830

\section{ข้อ Battelle}


NOTICE

This report was prepared as an account of work sponsored by the United States Government. Neither the United States nor the Energy Research and Development Administration, nor any of their employees, nor any of their contractors, subcontractors, or their employees, makes any warranty, express or implied, or assumes any legal liability or responsibility for the accuracy, completeness or usefulness of any imformation, apparatus, product or process disclosed, or represents that its use would not infringe privately owned rights.

PACIFIC NORTHWEST LABORATORY

operated by

BATTELLE

for the

ENERGY RESEARCH AND DEVELOPMENT ADMINISTRATION

Under Contract E(45-1)-1830

Printed in the United States of America

Available from

National Technical Information Service

U.S. Department of Commerce

5285 Port Royal Road

Springfield, Virginia 22151

Price: Printed Copy \$5.00: Microfiche $\$ 2.25$ 
33679000626798

CARBON-14 PRODUCTION IN FUSION REACTORS

by

R. D. Scheele and L. L. Burger

September 1976

BATTELLE

Pacific Northwest Laboratories

Richland, Washington 99352 


\section{SUMMARY}

Calculations based on existing composition data were performed to estimate the order of magnitude and the final 1ocation of ${ }^{14} \mathrm{C}$ in fusion reactors. These calculations indicate that approximately $8 \mathrm{Ci} /$ day, formed principally by ${ }^{14} \mathrm{~N}$ activation, will be produced in the UWMAK-II reference reactor $(5,000 \mathrm{MWth})$. If $\mathrm{Nb}-1 \% \mathrm{Zr}$ is used as the structural material instead of stainless steel 316 this quantity will be more than doubled. No information is available on the form of the ${ }^{14} \mathrm{C}$ produced, but reduced forms such as carbides, hydrocarbons and perhaps CO may be produced. Most of the ${ }^{14} \mathrm{C}$ may remain fixed in structural and other reactor materials until the material is reclaimed. Activation of air in the plasma chamber would be an immediate concern.

There is presently a lack of developed technology for control and fixation of ${ }^{14} \mathrm{C}$. Systems which could be used include collection with molecular sieves or cryogenic traps followed by fixation as calcium carbonate. This assumes that $\mathrm{CO}_{2}$ and $\mathrm{CO}$ and gaseous hydrocarbons are the species produced. Studies should be performed to determine the chemical form of the ${ }^{14} \mathrm{C}$ produced in the plasma, in the different materials, and its ease of removal. Transfer between components should be investigated. A review should be made of the nitrogen impurity levels in reactor component materials and methods of removal. Finally some consideration must be given to methods of fixation and storage. 


\section{CONTENTS}

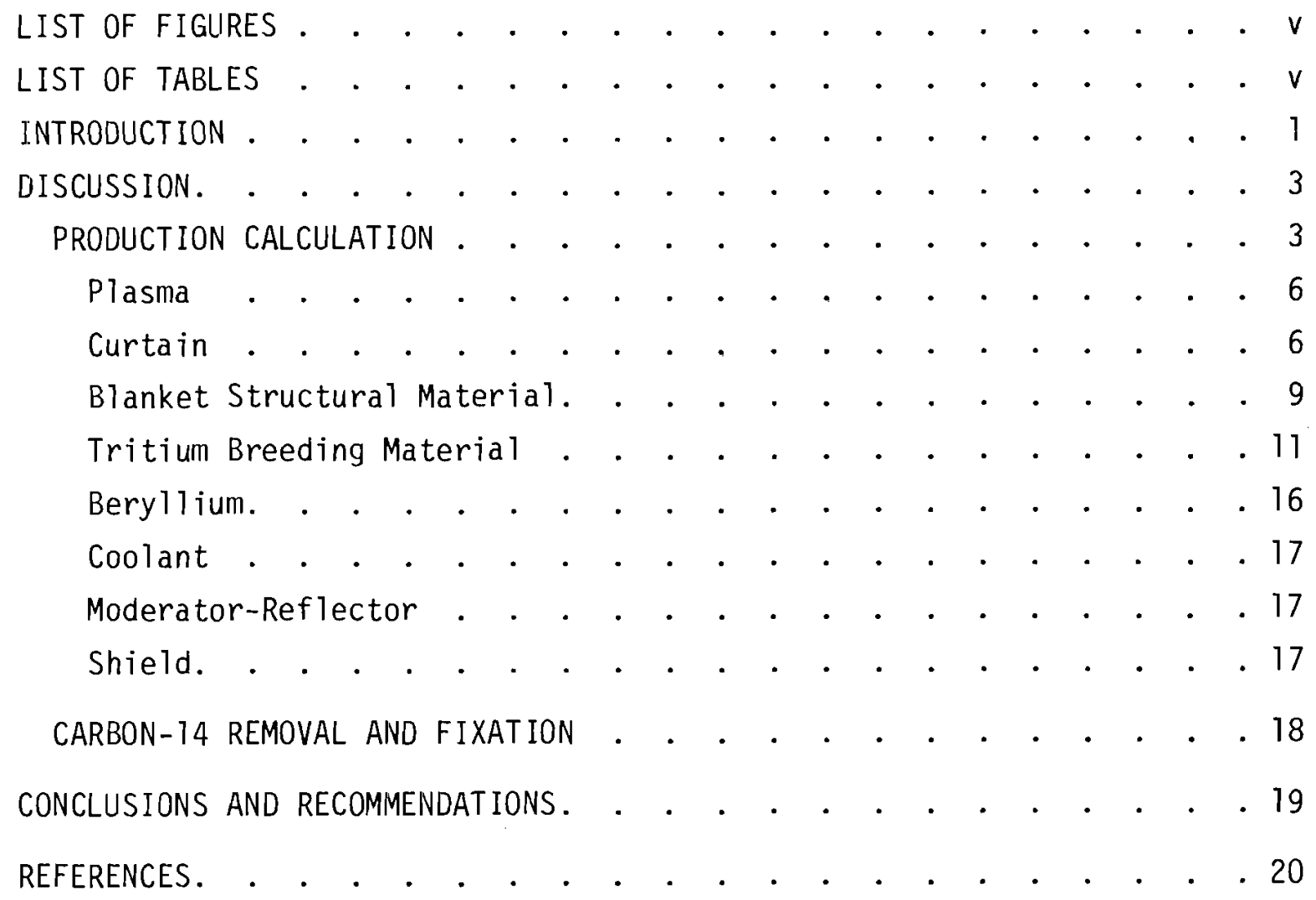




\section{LIST OF FIGURES}

1 A Schematic of UWMAK-II Blanket and Shield. . . . . . 5

2 University of Wisconsin CTR Blanket, Shield and

Magnet Structure for 5,000 MWth System, UWMAK-I. . . . . . 15

\section{LIST OF TABLES}

1 Carbon-14 Production Reactions . . . . . . . . . . 4

2 Summary of the Neutron Environment for UWMAK-II Solid Materials. . . . . . . . . . . . . 4

3 Calculated Carbon-14 Production. . . . . . . . . . . 7

4 Impurities in Graphite. . . . . . . . . . . . . . 9

5 Typical Chemical Analysis of Commercial 316 SST . . . . . 10

6 Composition of Commercial Nb-1\% $\operatorname{Zr}$ Alloy. . . . . . . . 10

8 Typical Impurities Found in High-Purity Lithium . . . . . 14

9 Chemical Composition Limits for Commercial Grade Beryllium QMV. . . . . . . . . . . . . . . 16 


\section{INTRODUCTION}

With expanded efforts and continued advances in plasma physics, engineering, and materials in the fusion reactor field, more attention is being directed towards environmental aspects.

Tritium has been the isotope of major concern because of the tremendous amounts involved in fusion reactors. Metal activation products have also received considerable attention. Although the behavior of carbon-14 $\left({ }^{14} \mathrm{C}\right)$ as well as its natural production, distribution, reactions, and biological impact have been well documented, the contribution to the world's ${ }^{14} \mathrm{C}$ inventory from the nuclear industry has only recently been addressed. Leipunskii, (1) Pauling, (2) and Totter (3) reviewed in 1957 and 1958 the effects of ${ }^{14} \mathrm{C}$ and the significant contribution from weapons testing. However, it was not until a decade later that Harkness and Walton (4) pointed out that by 1963 the ${ }^{14} \mathrm{C}$ inventory in the troposphere of the Northern Hemisphere had doubled while the dilution by "dead" fossil fuel carbon was only 3\%. Since 1973, Bonka, (5) Rublevskii, (6) Magno, (7) Brooks, $(8)$ and Snider ${ }^{(9)}$ have recently reviewed the ${ }^{14} \mathrm{C}$ production from the nuclear power industry. As a result of these studies, the sources and production rates are reasonably well established. The chemical form of the ${ }^{14} \mathrm{C}$ and the degree of release has not in most instances been experimentally determined. The behavior of $\mathrm{CO}_{2}$ which is the eventual form of most of the ${ }^{14} \mathrm{C}$ is well known, and its relatively short turnover time of approximately 3 years ${ }^{(4)}$ in the biosphere and eventual irreversible deposition in the deep ocean mitigates the effect of the long ${ }^{14} \mathrm{C}$ decay half-life of 5,720 years. The weapons ${ }^{14} \mathrm{C}$ decay data presented by Brooks ${ }^{(8)}$ suggest an atmospheric half-life of about 10 to 20 years.

A preliminary study dealing with information requirements necessary for fusion reactor environment support statements was assembled by Battelle, Pacific Northwest Laboratory in 1975. (10) The present report considers a single problem, ${ }^{14} \mathrm{C}$ from fusion reactors, the sources, amounts, final location, and form. 
There are two basic types of fusion reactor concepts. One concept employs magnetic fields to confine the plasma while the other uses an inertially confined plasma and high energy lasers to ignite the deuteriumtritium pellets. For the latter case, the conceptual design is less well defined, and the present discussion will be directed towards the magnetically confined type. UWMAK-II will be used as the reference reactor, but data for other types will be considered. Reactor descriptions can be found in Reference 11 and specific design details are available from design documents. $(12-20)$ 


\section{DISCUSSION}

\section{PRODUCTION_CALCULATION}

Carbon-14 is produced by neutron activation reactions. The $(D+T)$ plasma reaction which is to be used in first generation reactors produces $17.6 \mathrm{MeV}$ per $(D+T)$ reaction; included in this $17.6 \mathrm{MeV}$ is a $14.1 \mathrm{MeV}$ neutron. Therefore, the neutron spectrum is of high energy. The spectrum expected for the Princeton Tokamak can be found in their reference document. (12)

Table 1 lists the neutron reactions which involve ${ }^{14} \mathrm{C}$ along with their cross-sections for thermal and 14-MeV neutrons. Reactions 5 and 9 in Table 1 can be ignored since the threshold energies are greater than $14 \mathrm{MeV}$ while Reactions 7 and 8 added a negligible amount due to the low concentration of ${ }^{15} \mathrm{~N}$. Reactions 1,3 , and 4 then will be the significant production paths. Thus, the quantities of ${ }^{14} \mathrm{C}$ produced will depend on the concentration of air (or nitrogen) in gas or vacuum components and on the level of impurities (primarily nitrogen) in reactor components. It may be noted that the burnout of ${ }^{14} \mathrm{C}$ (Reaction 6) will be negligible.

The accurate determination of ${ }^{14} \mathrm{C}$ production in fusion reactors would require extensive multigroup calculations for the total neutron spectrum as the neutron absorption cross-sections for ${ }^{13} \mathrm{C}$ and nitrogen-14 $\left({ }^{14} \mathrm{~N}\right)$ vary over the energy range; oxygen-17 $\left({ }^{17} 0\right)$ has a constant cross-section over the energy range of interest. To simplify the calculations an approximation of the average energy must be made. Based on the Princeton Tokamak, (12) neutron energy varies essentially from $1 \mathrm{eV}$ to $14 \mathrm{MeV}$, with an average value of $10 \mathrm{keV}$. In this energy range the neutron cross-section of ${ }^{14} \mathrm{~N}$, ignoring resonances, is relatively constant. Therefore, the cross-section, $7.7 \times$ $10^{-2} \mathrm{~b}$, at $14 \mathrm{MeV}$ is used in the calculations. For ${ }^{13} \mathrm{C}(\mathrm{n}, \gamma){ }^{14} \mathrm{C}$, a crosssection of $10^{-6} \mathrm{~b}$ is used. The flux used in the average total flux, Figure 1 and Table 2, for a particular zone in UWMAK-II. (14) 


\section{TABLE 1. Carbon-14 Production Reactions}

\begin{tabular}{|c|c|c|c|c|c|}
\hline & Reaction & $\begin{array}{c}\text { Energy } \\
\text { Threshold, } \\
\text { Mev }\end{array}$ & $\begin{array}{c}\text { Isotopic } \\
\text { Abundance, } \%\end{array}$ & $\begin{array}{l}\text { Cross-Seg } \\
\text { Thermal }\end{array}$ & $\begin{array}{c}\text { jon, barns } \\
14.1 \mathrm{Mev}\end{array}$ \\
\hline & ${ }^{14} \mathrm{~N}(\mathrm{n}, \mathrm{p}){ }^{14} \mathrm{C}$ & 0 & 99.634 & 1.81 & $7.7 \times 10^{-2}(21)$ \\
\hline 2. & ${ }^{12} c(n, \gamma){ }^{13} c$ & 0 & 98.893 & $3.4 \times 10^{-3}$ & \\
\hline 3. & ${ }^{13} C(n, y){ }^{14} C$ & 0 & 1.107 & $0.9 \times 10^{-3}$ & $.7 \times 10^{-10(22)}$ \\
\hline 4. & ${ }^{17} \mathrm{n}(\mathrm{n}, \alpha)^{14} \mathrm{C}$ & 0 & 0.0374 & 0.235 & $0.25^{(22)}$ \\
\hline & ${ }^{17} \mathrm{O}\left(n, n^{3} \mathrm{He}\right){ }^{14} \mathrm{C}$ & 19.85 & 0.204 & & \\
\hline 6. & ${ }^{14} C(n, \gamma){ }^{15} C$ & 0 & N & $<7 \times 10^{-6}$ & \\
\hline 7. & ${ }^{15} \mathrm{~N}(n, d){ }^{14} \mathrm{C}$ & 8.5 & 0.366 & & \\
\hline 8. & ${ }^{15} \mathrm{~N}(\mathrm{n}, \mathrm{np})^{14} \mathrm{C}$ & 10.9 & 0.366 & & \\
\hline 9. & ${ }^{16} \mathrm{O}\left(\mathrm{n},{ }^{3} \mathrm{He}\right){ }^{14} \mathrm{C}$ & 15.52 & y9.759 & & \\
\hline
\end{tabular}

TABLE 2. Summary of the Neutron Environment for UWMAK-II Solid Materials (14)

\begin{tabular}{|c|c|c|c|c|c|}
\hline \multirow[b]{2}{*}{ Function } & \multirow[b]{2}{*}{ Material } & \multirow{2}{*}{$\begin{array}{l}\text { Uistance from } \\
\text { First Wall, cm }\end{array}$} & \multicolumn{3}{|c|}{ Neutron Flux, $\mathrm{n} / \mathrm{cm}^{2}-\mathrm{sec}$} \\
\hline & & & $>13.5 \mathrm{Mev}$ & $>1 \mathrm{Mev}$ & Total \\
\hline Curta in & Carbon & -2 & $9.5 \mathrm{E} 13$ & $4.4 E 74$ & 5.6 E14 \\
\hline \multirow[t]{3}{*}{ Structure } & $\begin{array}{l}316 \text { Stainiess } \\
\text { Steel }\end{array}$ & $0-89$ (Blanket) & $\begin{array}{l}9.5 \mathrm{E} 13 \text { to } \\
6.8 \mathrm{E} 10\end{array}$ & $\begin{array}{l}4.4 \mathrm{E} 14 \text { to } \\
5.6 \mathrm{E} 12\end{array}$ & $5.6 \mathrm{El} 4$ to $7.1 \mathrm{El} 2$ \\
\hline & & $89-189$ (Shield) & $\begin{array}{l}6.8 \text { E10 to } \\
5.2 \text { E05 }\end{array}$ & $\begin{array}{l}5.6 \mathrm{E} 72 \text { to } \\
6.4 \mathrm{t} 07\end{array}$ & $7.1 \mathrm{E}] 2$ to $7.1 \mathrm{EO}$ \\
\hline & & 204-302 (Magnet) & $\leq 5.2 \mathrm{E} 05$ & $\leq 6.4 \mathrm{E} 07$ & $\leq 7.1 巨 07$ \\
\hline \multirow[t]{2}{*}{ Breeder } & $\mathrm{Li}_{2} \mathrm{Al}_{2}{ }^{\mathrm{O}} 4$ & $2-4.5$ & $\begin{array}{l}7.1 \text { t } 13 \text { to } \\
6.0 \mathrm{E} 13\end{array}$ & $\begin{array}{l}4.0 \text { El4 to } \\
3.9 \text { El4 }\end{array}$ & b.2 E14 to $4.8 \mathrm{El} 4$ \\
\hline & & $23-32$ & $\begin{array}{l}1.5 \mathrm{E} 13 \text { to } \\
8.7 \mathrm{E} 12\end{array}$ & $\begin{array}{l}2.1 \mathrm{E} 14 \text { to } \\
1.5 \mathrm{E} 14\end{array}$ & $2.8 \mathrm{El} 4$ to $1.9 \mathrm{El} 4$ \\
\hline $\begin{array}{l}\text { Neutron } \\
\text { Multiplier }\end{array}$ & Beryl1ium & $5-22$ & $\begin{array}{l}5.2 \text { E13 to } \\
1.6 \mathrm{E} 13\end{array}$ & $\begin{array}{l}3.9 E 14 \text { to } \\
2.1 \text { E14 }\end{array}$ & $4.8 \mathrm{E} 14$ to $2.8 \mathrm{E} 14$ \\
\hline Reflector & Carbon & $32-70$ & $\begin{array}{l}8.7 \mathrm{E} 12 \text { to } \\
2.3 \mathrm{E} 11\end{array}$ & $\begin{array}{l}1.5 \mathrm{E} 14 \text { to } \\
1.4 \mathrm{E} 13\end{array}$ & $1.9 \mathrm{E} 14$ to $4.0 \mathrm{E} 13$ \\
\hline Shielding & $\begin{array}{l}\text { Lead, } \mathrm{B}_{4} \mathrm{C} \text {, } \\
\text { Stainless Steel }\end{array}$ & $89-789$ & $\begin{array}{l}6.8 \text { E10 to } \\
5.2 \text { E05 }\end{array}$ & $\begin{array}{l}6.4 \text { El2 to } \\
7.1 \text { E07 }\end{array}$ & $7.7 \mathrm{E} 13$ to $7.7 \mathrm{E} 07$ \\
\hline $\begin{array}{l}\text { Magnet } \\
\text { Materials }\end{array}$ & $\begin{array}{l}\text { Copper, } \\
\text { Niobium-Titanium }\end{array}$ & $204-302$ & $-5.2 \mathrm{E} 05$ & $<7.1$ E07 & $<7.1 E 07$ \\
\hline
\end{tabular}




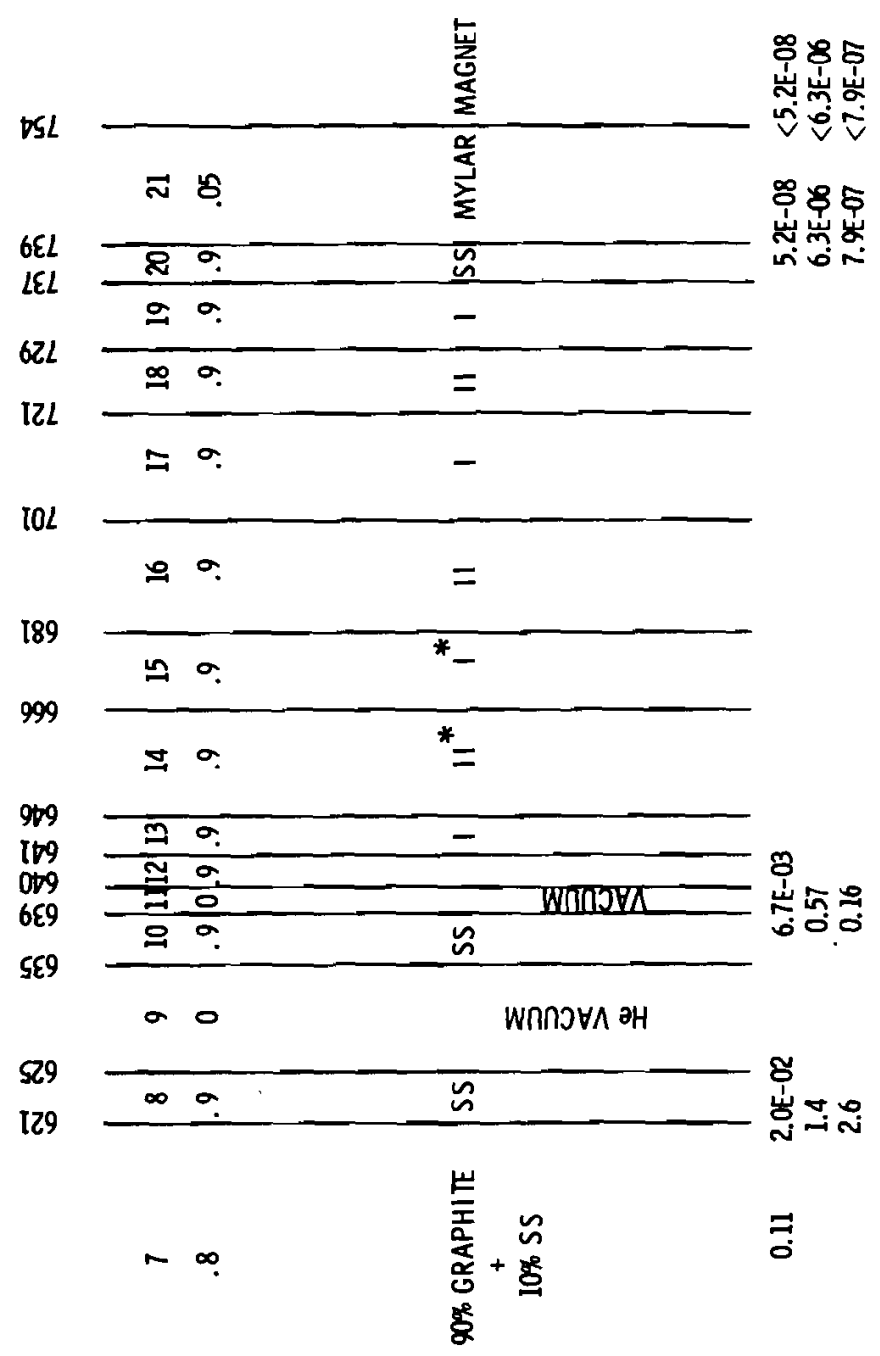

政

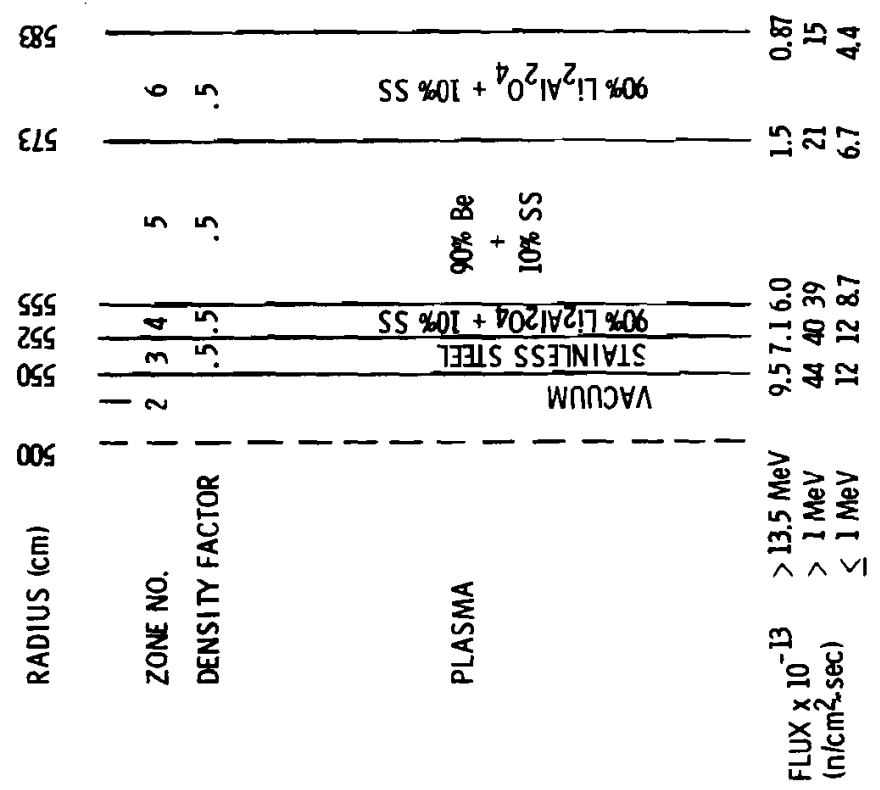

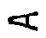

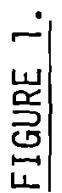


The ${ }^{14} \mathrm{C}$ produced is calculated from the product of the time, volume, concentration, and cross-section of the reacting nuclide and the neutron flux. The decay term and the ${ }^{14} \mathrm{C}$ transmutation term can be ignored because of the long half-life of ${ }^{14} \mathrm{C}, 5,720 \mathrm{y}$, and the very small cross section (Table 1).

Using these data and the amounts and types of materials in the various regions, the total ${ }^{14} \mathrm{C}$ production is calculated. Where data were lacking, an approximation of 100 wppm was made. The regions are discussed separately below. Impurity level data in the 1iterature were presented in most cases as ppm. We interpreted ppm as wppm as opposed to appm and made our calculations accordingly.

\section{Plasma}

The production of ${ }^{14} \mathrm{C}$ in the plasma will be due to air inleakage. This has been estimated to be $0.1 \%$ of the plasma chamber volume (13) which at STP will be $3.47 \times 10^{2}$ moles of air. The calculated quantities of ${ }^{14} \mathrm{C}$ produced per day are presented in Table 3 . The only significant producer is the ${ }^{14} \mathrm{~N}(n, p){ }^{14} \mathrm{C}$ reaction. Production from ${ }^{13} \mathrm{C}$ and $17_{0}$ is insignificant in this case, and in any other case when impurity activation is the sole source. The result is due to the small cross-section of ${ }^{13} \mathrm{C}$ and the sma 11 isotopic abundance of ${ }^{17} 0$, respectively.

The ${ }^{14} \mathrm{C}$ produced in this region could react with the oxygen impurity to form CO, but more likely with the residual deuterium or tritium fuel to form hydrocarbons.

\section{Curtain}

A carbon curtain has been proposed for use in UWMAK-II to protect the first wall from the energetic alpha particles and to partially attenuate the neutron flux. Carbon-14 production from ${ }^{13} \mathrm{C}$ in the curtain has been calculated to be $6.7 \times 10^{-3} \mathrm{Ci} /$ day. (14) This number is evidently based on the thermal neutron cross-section. Calculations based on the volume of the 


\section{TABLE 3. Calculated Carbon-14 Production}

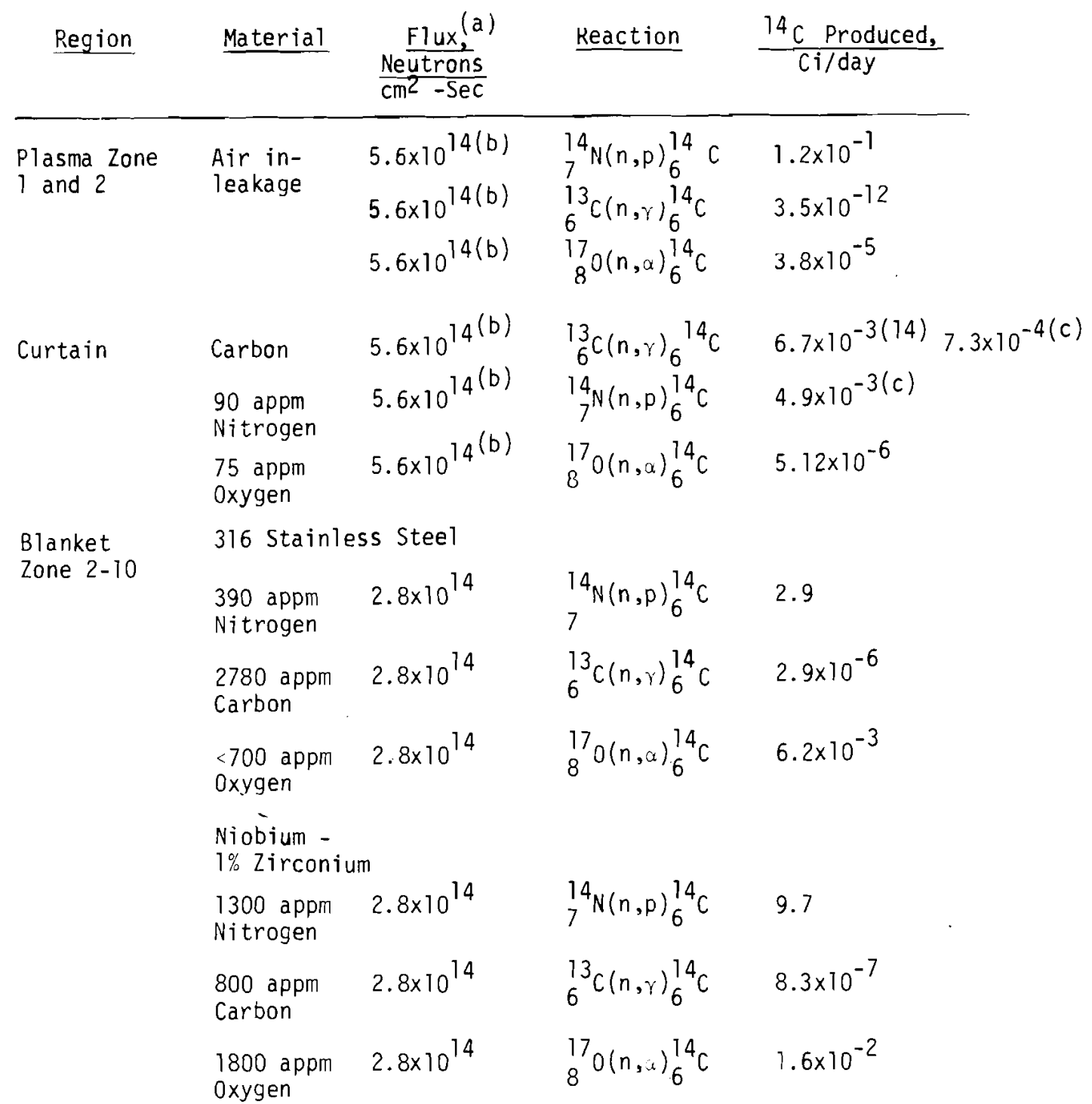

Impurity Data for Nimonic PE-16 Unavailable

Blanket

Zone 4

Zone $4-6^{(13)}$ UWMAK-I
$\mathrm{Li}_{2} \mathrm{Al}_{2}{ }_{2}{ }_{4}$
$5.0 \times 10^{14}$
${ }_{8}^{17} 0(n, \alpha){ }_{6}^{14} \mathrm{C}$
$7.8 \times 10^{-1}$
940 appm
$5.0 \times 10^{14}$
${ }_{7}^{14} \mathrm{~N}(\mathrm{n}, \mathrm{p}){ }_{6}^{14} \mathrm{C}$
1.2
$1100 \mathrm{appm}$
$5.0 \times 10^{14}$
${ }_{6}^{13} \mathrm{C}(\mathrm{n}, \gamma){ }_{6}^{14} \mathrm{C}$
$2.1 \times 10^{-7}$
Carbon (d)

Lithium

\begin{tabular}{|c|c|c|c|}
\hline $\begin{array}{l}15 \text { appm } \\
\text { Nitrogen }\end{array}$ & $2.6 \times 10^{14(13)}$ & ${ }_{7}^{14} N(n, p){ }_{6}^{14} \mathrm{C}$ & $2.7 \times 10^{-1}$ \\
\hline $\begin{array}{l}250 \text { app } \\
\text { vitroge }\end{array}$ & $2.6 \times 10^{14(13)}$ & ${ }_{7}^{14} N(n, p){ }_{6}^{14} C$ & 4.5 \\
\hline
\end{tabular}




\section{TABLE 3. (contd)}

\begin{tabular}{|c|c|c|c|c|}
\hline Region & Material & $\frac{\text { Flux, }}{\text { Neutrons }^{2}}$ & Reaction & $\frac{{ }^{14} \mathrm{C} \text { Produced, }}{\mathrm{Ci} / \mathrm{day}}$ \\
\hline \multirow{5}{*}{$\begin{array}{l}\text { Zone } 6 \\
\text { UWMAK-II }\end{array}$} & $\begin{array}{l}40 \text { appm } \\
\text { Oxygen }\end{array}$ & $2.6 \times 10^{14(13)}$ & ${ }_{8}^{17} O(n, \alpha){ }_{6}^{14} \mathrm{C}$ & $9.5 \times 10^{-4}$ \\
\hline & $\begin{array}{l}58 \text { appm } \\
\text { Carbon (d) }\end{array}$ & $2.6 \times 10^{14(13)}$ & ${ }_{6}^{13} \mathrm{C}(\mathrm{n}, \gamma){ }_{6}^{14} \mathrm{C}$ & $1.5 \times 10^{-7}$ \\
\hline & $\mathrm{Li}_{2} \mathrm{Al}_{2}{ }^{\mathrm{O}} 4$ & $2.4 \times 10^{14}$ & ${ }_{8}^{17} G(n, x){ }_{6}^{14} C$ & 1.3 \\
\hline & $\begin{array}{l}940 \text { appm } \\
\text { Nitrogen }(d)\end{array}$ & $2.4 \times 10^{14}$ & $\left.{ }_{7}^{14} \mathrm{~N}(\mathrm{n}, \mathrm{p})\right|_{5} ^{14} \mathrm{C}$ & 2.1 \\
\hline & $\begin{array}{l}1100 \text { appri } \\
\text { Carbon }(d)\end{array}$ & $2.4 \times 10^{14}$ & ${ }_{6}^{13} \mathrm{C}\left(\mathrm{n, \gamma},{ }_{6}^{14} \mathrm{C}\right.$ & $3.4 \times 10^{-7}$ \\
\hline \multirow{5}{*}{$\begin{array}{l}\text { Zone } 8^{(13)} \\
\text { UWMAK-I }\end{array}$} & Lithium & & & \\
\hline & $\begin{array}{l}15 \text { appm } \\
\text { Nitrogen }\end{array}$ & $2.0 \times 10^{13(\mathrm{e})}$ & $7_{7}^{14} N(n, p){ }_{6}^{14} C$ & $2.0 \times 10^{-3}$ \\
\hline & $\begin{array}{l}250 \text { appm } \\
\text { Ni trogen }\end{array}$ & $2.0 \times 10^{13(e)}$ & ${ }_{7}^{14} \mathrm{~N}(n, p){ }_{6}^{14} \mathrm{C}$ & $3.4 \times 10^{-2}$ \\
\hline & $\begin{array}{l}40 \text { appm } \\
\text { 0xygen }\end{array}$ & $2.0 \times 10^{13(e)}$ & ${ }_{8}^{17} 0(n, a){ }_{6}^{14} \mathrm{C}$ & $7.2 \times 10^{-6}$ \\
\hline & $\begin{array}{l}58 \text { appm } \\
\text { Carbon (d) }\end{array}$ & $2.0 \times 10^{13(e)}$ & ${ }_{6}^{13} C(n, i){ }_{6}^{14} C$ & $1.2 \times 10^{-9}$ \\
\hline
\end{tabular}

Impurity Data for Flibe Unavailable

(53.1\% BeF $2,46.9 \% \mathrm{LiF}$ )

Blanket

Zone 5

\begin{tabular}{|c|c|c|c|}
\hline \multicolumn{4}{|l|}{ Beryllium } \\
\hline $\begin{array}{l}5,400 \text { app:? } \\
\text { oxygen }\end{array}$ & $3.8 \times 10^{14}$ & ${ }_{8}^{17} O(n, \alpha){ }_{6}^{14} \mathrm{C}$ & $4.3 \times 10^{-2}$ \\
\hline $\begin{array}{l}500 \text { appmi } \\
\text { Carbon }\end{array}$ & $3.8 \times 10^{14}$ & ${ }_{6}^{13} c(n, \gamma){ }_{6}^{14} c$ & $2.3 \times 10^{-7}$ \\
\hline $\begin{array}{l}64 \text { appm } \\
\text { Nitrogen (d) }\end{array}$ & $3.8 \times 10^{4}$ & ${ }_{7}^{14} \mathrm{~N}(\mathrm{n}, \mathrm{p}){ }_{6}^{14} \mathrm{C}$ & $4.1 \times 10^{-1}$ \\
\hline $\begin{array}{l}\text { Graphite } \\
\text { Carbon }\end{array}$ & $1.2 \times 10^{14}$ & ${ }_{6}^{13} c(n, \gamma){ }_{6}^{14} c$ & $4.9 \times 10^{-4}$ \\
\hline $\begin{array}{l}\text { So appm } \\
\text { Nitrogei }\end{array}$ & $1.2 \times 10^{14}$ & ${ }_{7}^{14} \mathrm{~N}(n, p){ }_{6}^{14} \mathrm{C}$ & $3.0 \times 10^{-2}$ \\
\hline $\begin{array}{l}15 \text { appm } \\
0 x y g e n(d)\end{array}$ & $1.2 \times 10^{14}$ & ${ }_{8}^{17} 0(n, \alpha){ }_{6}^{14} C$ & $3.2 \times 10^{-5}$ \\
\hline
\end{tabular}

Shield Lead

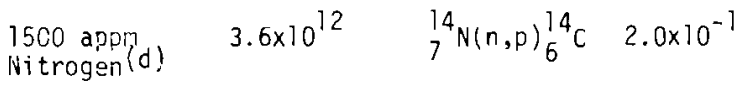

(a) See Text.

(b) Flux in Pląsma is assumed same as first wall.

(c) $1.4 \times 10^{-6} \mathrm{~cm}^{3}$ graphite at $2.25 \mathrm{~g} / \mathrm{cm}^{3}$.

(d) Estimated impurity level of $100 \mathrm{kppm}$, data were unavailable.

(e) Flux calculated using distance from first wall of UWMAK-I and flux of UWMAK-II at that distance. 
curtain, a curtain density of $2.25 \mathrm{~g} / \mathrm{cm}^{3}$ for pure graphite, the impurity data presented in Table 4, and a neutron cross-section for $10 \mathrm{keV}$ neutrons give $7.3 \times 10^{-4} \mathrm{Ci} /$ day from ${ }^{13} \mathrm{C}$ and $4.9 \times 10^{-3} \mathrm{Ci} /$ day from 90 appm nitrogen. The contribution from ${ }^{17} 0$ will be negligible.

TABLE 4. Impurities in Graphite ${ }^{(23)}$

$\begin{array}{lcrr}\text { Element } & \text { Concentration, wppm } & & \text { appm } \\ \text { Lithium } & 1 & 2 \\ \text { Boron } & 162 & 180 \\ \text { Nitrogen } & 100 & 90 \\ \text { Silicon } & 17 & 10 \\ \text { Iron } & 50 & 10\end{array}$

(a) ppm has been interpreted as wppm

The ${ }^{14} \mathrm{C}$ produced in the curtain should remain there and thus would be a hazard only when the curtain is replaced or an attempt to reclaim the graphite is made. However, it must be pointed out that no experimental data are available for the behavior of ${ }^{14} \mathrm{C}$ generated in graphite.

Blanket Structural Material

A number of structural materials are being considered for use in fusion reactors including stainless steels, nimonic PE-16, niobium, vanadium, and molybdenum. (10) The first three may be used in a first generation reactor. However, the availability and technology of niobium is such that it may have limited application in early units.

The compositions of stainless steel-316 and niobium-1\% zironium are presented in Tables 5 and 6 . We were unable to locate the oxygen, nitrogen, and carbon content of nimonic PE-16 (43\% nicke1, 39\% iron, $18 \%$ chromium). Impurity levels appear to be around 100 wppm for all metals of this type, so the substitution of PE-16 for stainless steel should make little difference in the ${ }^{14} \mathrm{C}$ yields. 
TABLE 5. Typical Chemical Analys is of Commercial 316 SST (14)

\begin{tabular}{|c|c|c|c|c|}
\hline Element & wppm & vppm & g-Atom/MT & appm \\
\hline Aluminum & 500 & 1000 & 18.5 & 1,030 \\
\hline Arsenic & 300 & 230 & 4.0 & 220 \\
\hline Boron & 10 & 52 & 0.9 & 50 \\
\hline Cobalt & 500 & 500 & 8.5 & 470 \\
\hline Chromium & 180,000 & 195,000 & $3,461.5$ & 192,000 \\
\hline Copper & 1,000 & 900 & 15.7 & 870 \\
\hline Iron & 626,000 & 626,000 & 11200.0 & 670,000 \\
\hline Manganese & 20,000 & 20,000 & 364.0 & 20,200 \\
\hline Molybdenum & 20,000 & 12,000 & 208.5 & 11,500 \\
\hline Niobium & 500 & 300 & 5.4 & 300 \\
\hline Nickel & 140,000 & 134,000 & $2,380.0$ & 132,000 \\
\hline Phosphorus & 200 & 400 & 6.5 & 360 \\
\hline Sulfur & 100 & 200 & 3.1 & 170 \\
\hline Silicon & 7,000 & 14,000 & 249.2 & 13,800 \\
\hline Tantalum & 200 & 60 & 1.1 & 60 \\
\hline Titanium & 100 & 100 & 2.1 & 120 \\
\hline Vanadium & 2,000 & 2,200 & 39.3 & 2,180 \\
\hline Carbon & 600 & 2,800 & 50.0 & 2,780 \\
\hline Nitrogen & 100 & 400 & 7.1 & 390 \\
\hline Oxygen & $<200$ & $<700$ & $<12.5$ & $<700$ \\
\hline
\end{tabular}

TABLE 6. Composition of Commercial Nb-1\% $\mathrm{Zr} \mathrm{A1loy}(15,16)$

\begin{tabular}{|c|c|c|c|c|c|}
\hline \multirow{2}{*}{ Element } & \multicolumn{2}{|c|}{ Content, } & \multirow[b]{2}{*}{ Element } & \multicolumn{2}{|c|}{ Content, } \\
\hline & wppoil $(a)$ & appm & & wppm(a) & appm \\
\hline Tungsten & 300 & 150 & Oxygen & 300 & 1,800 \\
\hline Molybdenum & 100 & 100 & Nitrogen & 200 & 1,300 \\
\hline Tantalum & 1,000 & 500 & Hydrogen & 20 & 1,900 \\
\hline Hafnium & 100 & 50 & Carbon & 100 & 800 \\
\hline Zirconium & 10,000 & 10,000 & Iron & 50 & 80 \\
\hline Niobium & 985,000 & 991,000 & Nickel & 20 & 30 \\
\hline
\end{tabular}

(a) ppm interpreted as wppm 
Carbon-14 production for these materials in the blanket and in other locations is given in Table 3 . Nitrogen is again the only major producer of the carbon radioisotope, $2.9 \mathrm{Ci} /$ day in stainless and $9.7 \mathrm{Ci} /$ day in niobium- $1 \%$ zirconium.

It would be expected that ${ }^{14} \mathrm{C}$ produced in structural materials would exist as a carbide and be relatively immobile. The possibility of transfer by extraction with molten lithium or molten salts such as "flibe" (1ithium, beryllium, fluoride), assuming that contact is possible, can be predicted from consideration of thermodynamic stabilities and solubilities. Some data for compounds of interest are listed in Table 7. The question of carbon transfer (as well as nitrogen, oxygen and other elements) between phases is of extreme importance in corrosion control and has been extensively examined. Beskorovainyi ${ }^{(24)}$ has reviewed the carbon-molten $1 i$ thium-metal system and the general compatibility problem is discussed by Smith and Natesan. (25) Over the temperature range of interest the stability of the nitride increases in the order lithium, molybdenum, chromium, vanadium, niobium, yttrium, titanium, zirconium and for the carbide, lithium, yttrium, molybdenum, chromium, vanadium, titanium, zirconium and niobium. Nitrogen transfer before activation may be minimal, and it would appear ${ }^{14} \mathrm{C}$ (and nitrogen) that finds its way into a lithium stream could be scavenged by zirconium or yttrium. It should be reemphasized that the data of Table 7 indicate stabilities of the pure compounds. For the practical case, solubility and diffusion data as well as chemical rate data are extremely important.

\section{Tritium Breeding Material}

A11 of the conceptual reactors use lithium to breed tritium. Molten lithium, $\mathrm{Li}_{2} \mathrm{Al}_{2} \mathrm{O}_{4}$, and molten "flibe" (a eutectic mixture of LiF, BeF ${ }_{2}$ ) are the prime candidates at this time. The impurity data for lithium are found in Table 8. Impurity data for $\mathrm{Li}_{2} \mathrm{Al}_{2} \mathrm{O}_{4}$ and "flibe" are unavailable so calculations were performed using $100 \mathrm{wppm}$ each for nitrogen, oxygen and carbon impurity levels. 
TABLE 7. Free Energies of Formation of Oxides, Nitrides, Carbides, and Fluorides $(a)\left(\Delta G^{\circ}, \mathrm{Kcal} / \mathrm{gm}\right.$ atom, oxygen, nitrogen, carbon, and iron)

\begin{tabular}{|c|c|c|c|c|}
\hline & Reference & $500^{\circ} \mathrm{K}$ & $1000^{\circ} \mathrm{K}$ & $1500^{\circ} \mathrm{K}$ \\
\hline $\mathrm{Al}_{2}, \mathrm{O}_{3}$ & 26 & -120.9 & -108.4 & -95 \\
\hline $\mathrm{Li}_{2}{ }^{\mathrm{O}}$ & 25 & -128.0 & -111.6 & -95.2 \\
\hline $\mathrm{ZrO}_{2}$ & 25 & -119.2 & -108.0 & -87.8 \\
\hline TiO & 25 & -111.6 & -101.0 & -90.4 \\
\hline BeO & 26 & -131.4 & -119.8 & $(-109.2)$ \\
\hline$V_{9} O$ & 25 & -103.4 & -79.7 & -56 \\
\hline $\mathrm{Ta}_{2} \mathrm{O}_{5}$ & 26 & -87.0 & -76.7 & -67.1 \\
\hline $\mathrm{FeO}$ & 26 & -55.3 & -47.4 & $-3 y .1$ \\
\hline $\mathrm{Mn}_{2} \mathrm{O}_{3}$ & 26 & -64.0 & -53.8 & -43.6 \\
\hline NbO & 25 & -89.6 & -78.9 & -68.2 \\
\hline $\mathrm{Cr}_{2} \mathrm{O}_{3}$ & 25 & -80.0 & $-6 y .7$ & -59.4 \\
\hline$Y_{2} O_{3}$ & 26 & -139.5 & -127.3 & -115.5 \\
\hline NiO & 25 & -46.1 & -35.7 & -25.6 \\
\hline $\mathrm{CO}_{2}$ & 27 & -47.2 & -47.3 & -47.4 \\
\hline $\mathrm{H}_{2} \mathrm{O}$ & 27 & -52.4 & -46.0 & -39.3 \\
\hline TiC & 25 & -42.6 & -41.5 & -40.3 \\
\hline $\operatorname{ZrC}$ & 25 & -43.0 & -41.9 & -40.8 \\
\hline$V_{2} C$ & 25 & -34.6 & -34.1 & -33.6 \\
\hline $\mathrm{Nb}_{2} \mathrm{C}$ & 25 & -45.5 & -45.0 & -44.5 \\
\hline $\mathrm{TaC}$ & 26 & -37.8 & -36.4 & -34.3 \\
\hline $\mathrm{Cr}_{7} \mathrm{C}_{3}$ & 28 & -19 & -20 & $(-22)$ \\
\hline $\mathrm{Cr}_{23} \mathrm{C}_{6}$ & 28 & -23 & -26 & -28 \\
\hline$Y C_{2}$ & 28 & -12.9 & -14.0 & -15.3 \\
\hline $\mathrm{GdC}_{2}$ & 28 & -14.9 & -15.5 & -16.8 \\
\hline $\mathrm{Mn}_{7} \mathrm{C}_{3}$ & 28 & 0 & -6 & -12 \\
\hline $\mathrm{Fe}_{3} \mathrm{C}$ & 26 & +3.8 & +0.8 & -0.65 \\
\hline $\mathrm{Ni}_{3} \mathrm{C}$ & 28 & +7 & +5 & +4 \\
\hline $\mathrm{Al}_{4} \mathrm{C}_{3}$ & 28 & -12.0 & -12.3 & -11.5 \\
\hline $\mathrm{Mo}_{2} \mathrm{C}$ & 26 & +2.9 & -10.3 & -23.4 \\
\hline$L i_{2} C_{2}$ & 26 & -4.25 & -0.70 & +2.85 \\
\hline
\end{tabular}


TABLE 7. (contd)

\begin{tabular}{|c|c|c|c|c|}
\hline & Reference & $500^{\circ} \mathrm{K}$ & $1000^{\circ} \mathrm{K}$ & $1500^{\circ} \mathrm{K}$ \\
\hline $\mathrm{Be}_{2} \mathrm{C}$ & 27 & -20.7 & -19.0 & -17.2 \\
\hline YH & 28 & -61.0 & -50.9 & -40.3 \\
\hline $\mathrm{Nb}_{2} \mathrm{~N}$ & 25 & -54.0 & $-44 . y$ & -31.8 \\
\hline TiN & 25 & -69.4 & -58.3 & -47.3 \\
\hline $\mathrm{ZrN}$ & 25 & -75.9 & -64.8 & -53.7 \\
\hline AIN & 26 & -51.0 & $(-40)$ & $(-25)$ \\
\hline $\mathrm{Be}_{3} \mathrm{~N}_{2}$ & 26 & -56.6 & $(-47.2)$ & $(-38.9)$ \\
\hline $\mathrm{Li}_{3} \mathrm{~N}$ & 25 & -28.0 & -10.0 & +10.2 \\
\hline $\mathrm{Cr}_{2} \mathrm{~N}$ & 25 & -18.3 & -12.4 & -6.4 \\
\hline$M n_{5} N_{2}$ & 26 & -15.1 & $(-5)$ & -- \\
\hline $\mathrm{Fe}_{4} \mathrm{~N}$ & 26 & +3.1 & $+y .5$ & +14 \\
\hline VN & 25 & -30.4 & -20.4 & -10.4 \\
\hline $\mathrm{Mo}_{2} \mathrm{~N}$ & 25 & -8.9 & -1.3 & +6.3 \\
\hline $\mathrm{TaN}$ & 26 & -47.9 & -40.5 & -32.3 \\
\hline $\mathrm{BeF}_{2}$ & 27 & -113.3 & -104.3 & $-96.5(1 \mathrm{iq})$ \\
\hline $\mathrm{AlF}_{3}$ & 27 & -109.8 & -99.6 & -89.3 \\
\hline $\mathrm{ZrF}_{4}$ & 27 & -104.1 & -94.6 & $-87.2 @ 1400^{\circ} \mathrm{K}$ \\
\hline$Y F_{3}$ & 29 & -123 & -115 & -107 \\
\hline $\mathrm{MnF}_{2}$ & 26 & $(-8 b .5)$ & $(-78.5)$ & $(-73.2)$ \\
\hline $\mathrm{TiF}_{4}$ & 27 & -89.6 & -81.6 & -74.1 \\
\hline $\mathrm{NiF}_{2}$ & 26 & $(-70)$ & $(-62)$ & $(-54.2)$ \\
\hline $\mathrm{CrF}_{2}$ & 29 & -83 & -75 & -67 \\
\hline LiF & 27 & -136.1 & -123.7 & -115.5 \\
\hline $\mathrm{TaF}_{2}$ & 29 & $(-82)$ & $(-75)$ & $(-67)$ \\
\hline $\mathrm{NbF}_{5}$ & 29 & $(-62)$ & $(-59)$ & $(-55)$ \\
\hline$v F_{2}$ & 29 & $(-90)$ & $(-83)$ & $(-75)$ \\
\hline $\mathrm{MoF}_{6}$ & 27 & -55.8 & -49.7 & -- \\
\hline $\mathrm{MOF}_{5}$ & 29 & $(-60)$ & $(-58)$ & $(-54)$ \\
\hline $\mathrm{FeF}_{2}$ & 27 & -75.9 & -67.9 & -59.9 \\
\hline
\end{tabular}

(a) Data are for the normal state at the temperature indicated. 
TABLE 8. Typical Impurities Found in High-Purity Lithium $(15,16)$

\begin{tabular}{|c|c|c|c|c|c|}
\hline \multirow[b]{2}{*}{ Element } & \multicolumn{2}{|c|}{ Content, } & \multirow[b]{2}{*}{ Element } & \multicolumn{2}{|c|}{ Content, } \\
\hline & wppm(a) & appm & & wppm(a) & appm \\
\hline Silicon & $5-50$ & $1-12$ & Nickel & 100 & 10 \\
\hline Oxygen & 100 & 40 & Chromium & 100 & 10 \\
\hline Nitrogen & $30-500$ & $15-250$ & Tantalufi & 100 & 4 \\
\hline Calcium & 100 & 20 & Fluorine ${ }^{(b)}$ & 3,000 & 1,100 \\
\hline Sodium & 100 & 30 & Chlorine ${ }^{(b)}$ & 3,000 & 600 \\
\hline Potassium & 100 & 20 & & & \\
\hline Iron & 100 & 10 & & & \\
\hline
\end{tabular}

\footnotetext{
(a) ppm interpreted as wppm

(b) Fluorine and chlorine content arises from proposed use of LiF-LiCl eutectic to extract tritium from blanket of RTPR.
}

Carbon-14 production from the oxygen constituent in $\mathrm{Li}_{2} \mathrm{Al}_{2} \mathrm{O}_{4}$ amounts to $0.78 \mathrm{Ci} /$ day in Zone 4 (Figure 1) and $1.3 \mathrm{Ci} /$ day in Zone 6 (Figure 1). Based on 940 appm nitrogen in the $\mathrm{Li}_{2} \mathrm{Al}_{2} \mathrm{O}_{4}, 1.2$ and $2.1 \mathrm{Ci} /$ day will be produced in Zones 4 and 6 , respectively.

For the lithium coolant-breeder in Zones 4 through 6 (Figure 2) of UWMAK-I the computed amount ranges from 0.27 to $4.5 \mathrm{Ci} /$ day for the minimum and maximum nitrogen impurity levels. For Zone 8 , an estimated flux for the same location in UWMAK-II was used, values ranging from $2.0 \times 10^{-3}$ to $3.4 \times 10^{-2} \mathrm{Ci} /$ day are obtained. No calculations were performed for "flibe". Again, the ${ }^{14} \mathrm{C}$ production will depend on the nitrogen concentration of the material. Table 3 presents the calculated data for breeder materials. 


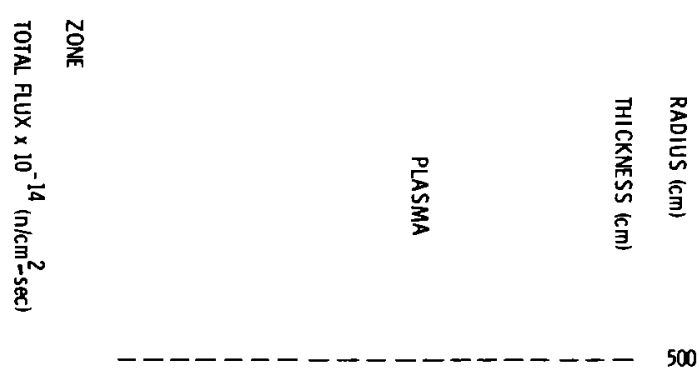

ơ

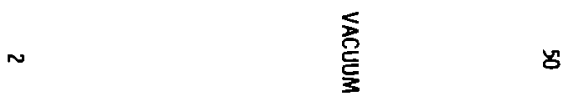

ํㅐㅇ

ᄋํㅇ

롤

$\stackrel{+}{5}$ 운

$\approx \Sigma$

ज ज

응

哑

도

率

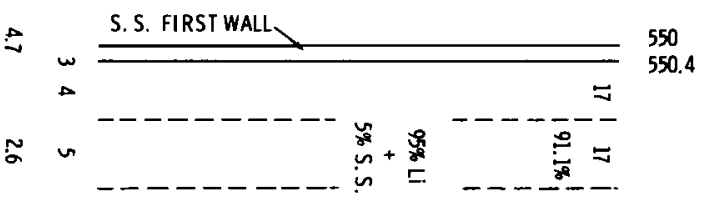

。

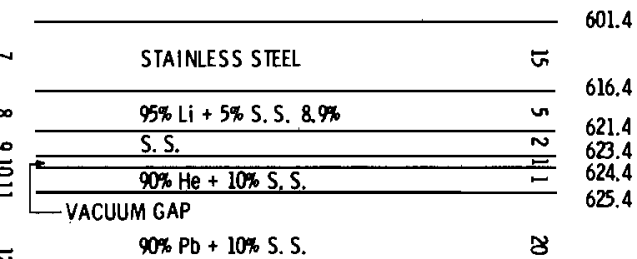

$\approx \quad 90 \% \mathrm{~Pb}+10 \%$ S.S.

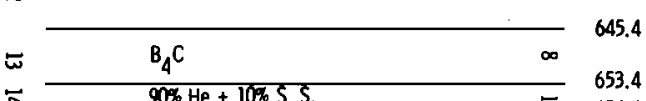

\begin{tabular}{lll}
\hline $90 \% \mathrm{He}+10 \% 5.5$. & 653.4 \\
& & 654.4
\end{tabular}

ज $\quad 90 \% \mathrm{~Pb}+10 \%$ S. S.

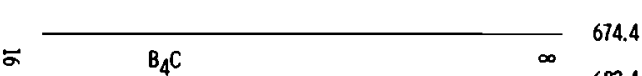

$=$\begin{tabular}{ll}
\hline $90 \% \mathrm{~Pb}+10 \% \mathrm{~S} . \mathrm{S}$. & 68.4 \\
$90 \% \mathrm{~Pb}+10 \% \mathrm{~S} . \mathrm{S} .4$ & -
\end{tabular}

$\therefore \quad$\begin{tabular}{lll}
$90 \% \mathrm{~Pb}+10 \% \mathrm{~S}, \mathrm{~S}$. & 5 & \\
\hline $\mathrm{B}, \mathrm{C}$ & 693.4
\end{tabular}

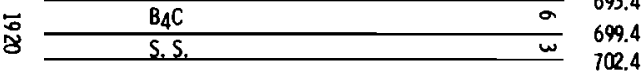

$\simeq \quad 95 \%$ VACUUM + 5\% MYLAR

7224

ก

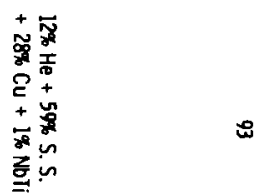


The fate of the ${ }^{14} \mathrm{C}$ produced in the breeder material is again dependent on the physical state, and the thermodynamics of the system (Table 7). The chemical form of the carbon produced in the $\mathrm{Li}_{2} \mathrm{Al}_{2} \mathrm{O}_{4}$ is unknown; potentially, the most stable compound is $\mathrm{Al}_{2} \mathrm{C}_{3}$, but it may never form under the conditions existing. In the $\mathrm{Li}_{2} \mathrm{Al}_{2} \mathrm{O}_{4}$ case the ${ }^{14} \mathrm{C}$ problem may emerge during blanket processing. The molten lithium or "flibe" systems may lose the carbon to structural materials as it is circulated or the lithium may lose it to the proposed purification system, a zirconium or yttrium getter. (13) In either of the latter cases, ${ }^{14} \mathrm{C}$ may only be a problem when the material is removed and reclaimed.

\section{Beryllium}

Beryllium is to be used as a neutron multiplier in the blanket to increase the tritium breeding. UWMAK-II has a zone of solid beryllium metal; Table 9 presents the composition of commercial-grade beryllium. Since no nitrogen content was located in the beryllium, calculations are based on 60 appm nitrogen. TABLE 9. Chemical Composition Limits for Commercial
Grade Beryllium QMV $(30)$

\begin{tabular}{lrrrr}
\multicolumn{1}{c}{ Element } & \multicolumn{2}{c}{ wppm } & \multicolumn{2}{c}{ appm } \\
\cline { 5 - 5 } Oxygen & & $4,500-9,600$ & $2,500-5,400$ \\
Iron & $800-1700$ & $100-300$ \\
Aluminum & $300-600$ & $100-200$ \\
Magnesium & $100-500$ & $40-200$ \\
Nickel & $200-800$ & $30-100$ \\
Chromium & $100-300$ & $20-500$ \\
Silicon & $500-800$ & $200-300$ \\
Boron & 2 & 2 \\
Carbon & 700 & 500
\end{tabular}


The amount of ${ }^{14} \mathrm{C}$ produced is presented in Table 3 . From 60 appm nitrogen $0.41 \mathrm{Cj} /$ day are prodcued. This number may be low as impurities in beryllium appear to be higher than the normal impurity levels in other metals. The oxygen level is high enough to contribute $0.04 \mathrm{Ci} /$ day. The ${ }^{14} \mathrm{C}$ produced should remain fixed in the metal in its lifetime in the reactor. Its fate outside of the reactor depends on the treatment of the spent beryllium.

\section{Coolant}

If the blanket material is not used as the coolant, an alternative is helium. The possibilities for ${ }^{14} \mathrm{C}$ production in this gas are greatly minimized by the high degree of purity, 2 appb, attainable. (31) It is a relatively simple process to remove nitrogen from helium. However, the helium coolant specified for a typical HTGR reactor shows 0.7 appm nitrogen. (32)

\section{Moderator-Reflector}

Graphite is typically chosen as the moderator-reflector material; however, stainless steel was chosen for UWMAK-I. Impurity content is presented in Table 4.

In UWMAK-II, $4.9 \times 10^{-8}$ and $2.99 \times 10^{-2} \mathrm{Ci} /$ day (Table 3 ) of ${ }^{14} \mathrm{C}$ will be produced from carbon and 90 appm nitrogen in the graphite. As was noted earlier, unless a large quantity is present, its contribution will be negligible.

$\underline{\text { Shield }}$

The materials which are to be used in the radiation shields are lead and boron carbide. No impurity data were located for either. The flux in this region is much lower, $10^{12} \frac{\text { neutrons }}{\mathrm{cm}^{2}-\mathrm{sec}}$, and the production rate would be quite sma11. For lead containing 1,500 appm nitrogen, $1.3 \times 10^{-2} \mathrm{Cj} /$ day would be produced in UWMAK-II (Table 3 ). Over long periods of time ${ }^{14} \mathrm{C}$ levels in the shield materials could become significant. 


\section{CARBON-14 REMOVAL AND FIXATION}

As mentioned above, ${ }^{14} \mathrm{C}$ produced in graphite, in metals, and in other solids is probably not very mobile and may largely remain in place. Some will migrate to interfaces and be transported by liquid or gas phases to regions of higher stability (see Table 7). No information is available on the chemical forms that may exist; presumably they would include carbon, metal carbides, $\mathrm{CO}, \mathrm{CO}_{2}$ and hydrocarbons. Reducing conditions exist in nearly all the cases examined, hence $\mathrm{CO}$ and $\mathrm{CO}_{2}$ production should be small. If hydrogen is present, the tendency in the high radiation field will be toward the production of simple saturated hydrocarbons. It is interesting to note that the ${ }^{14} \mathrm{C}$ in cover gas from a boiling water reactor $\left(\mathrm{H}_{2}-\mathrm{N}_{2}\right.$ atmosphere) was over $80 \% \mathrm{CH}_{4}$ and $\mathrm{C}_{2} \mathrm{H}_{6}$.

Removal methods may be unique for each reactor component, e.g., cryogenic trapping for plasma ash, and perhaps catalytic oxidation to $\mathrm{CO}_{2}$. For helium purification, molecular sieve or chemical trapping may be used. Some of the metal carbides are quite stable and may fix the ${ }^{14} \mathrm{C}$ until some processing step is performed. However, it should be noted that they are not in general thermodynamically stable with respect to reactions such as $\mathrm{MC}+\mathrm{O}_{2} \rightarrow \mathrm{MO}+\mathrm{CO}_{2}$ and $\mathrm{MO}+\mathrm{H}_{2} \mathrm{O} \rightarrow \mathrm{MO}+\mathrm{CH}_{4}$ and even (in some cases) $\mathrm{MC}+\mathrm{H}_{2} \rightarrow \mathrm{MH}+\mathrm{CH}_{4}$.

If environmental release of ${ }^{14} \mathrm{C}$ is not permitted, conversion to a solid such as calcium or barium carbonate has been proposed as an alternative. The carbonate would be transferred to a repository for storage. (34) 


\section{CONCLUSIONS AND RECOMMENDATIONS}

Our calculations for ${ }^{14} \mathrm{C}$ production from ${ }^{14} \mathrm{~N},{ }^{17} 0$, and ${ }^{13} \mathrm{C}$ neutron reactions in a 5,000 MWth toroidal fusion reactor indicate that $\sim 8 \mathrm{Ci} /$ day, principally from ${ }^{14} \mathrm{~N}$ if stainless steel is used as the structural material; the use of $\mathrm{Nb}-1 \% \mathrm{Zr}$ will double this quantity. This can be compared to the natural global production rate from cosmic rays of $6 \mathrm{~kg} / \mathrm{y}$ or $78 \mathrm{Ci} /$ day. of the ${ }^{14} \mathrm{C}$ produced, only $0.12 \mathrm{Ci} /$ day produced by activation of air inleakage into the plasma may be of immediate environmental concern. The remainder will be fixed in the structural or other reactor materials until this material is reclaimed, i.e., until sufficient time has passed for depletion of the other activated elements.

The ${ }^{14} \mathrm{C}$ produced by activation of air which has leaked into the plasma chamber would be removed in the ash treatment and could subsequently leak or be released to the environment. Further consideration of the behavior of ${ }^{14} \mathrm{C}$ in the plasma is indicated. In general, the chemical form of the ${ }^{14} \mathrm{C}$ produced is not known. Reducing conditions generally prevail leading to carbides and perhaps hydrocarbons. Experimental studies should be made to identify species and determine ease of removal and treatment. It should be noted that a wide range of materials is involved: gases, nonmetals, liquid and solid metals, and liquid and solid salts. The chemistry of carbon in each is quite different.

The impurity level in materials is very important, especially that of nitrogen. Missing data should be found and methods of minimizing the nitrogen content should be examined as should the migration of nitrogen between components. Methods of conversion of ${ }^{14} \mathrm{C}$ forms to $\mathrm{CO}_{2}$ or other form for fixation should also be evaluated along with methods of fixing the resulting compound for storage. Finally, the production data listed are only estimates and could be refined by using multigroup calculations along with better nitrogen impurity data. 


\section{REFERENCES}

1. 0. I. Leipunskii, "Harmful Effects of the Radioactivity from the Explosion of Pure Hydrogen Bombs and Ordinary Atomic Bombs." Atomic Energy (USSR), English Translation, 12:530, 1957.

2. L. Pauling, "Genetic and Somatic Effects of Carbon-14." Science, 128:1183, 1958.

3. J. R. Totter, M. R. Zelle, and H. Hollister, "Hazard to Man of Carbon-14." Science, 128:1490, 1958.

4. D. D. Harkness and A. Walton, "Carbon-14 in the Biosphere and Humans." Nature, 223:1216, 1969.

5. H. Bonka et a1., "Contamination of the Environment by Carbon-14 Produced in High Temperature Reactors." Kerntechnik, 15(7):297, 1973.

6. V. P. Rublevskii, A. Z. Zykova, and A. D. Turkin, Atomic Power as a Source of 14C Discharge. ORNL-Tr-2976, Oak Ridge National Laboratory, Oak Ridge, TN, 1973.

7. P. J. Magno, C. B. Nelson, and W. H. Ellett, "A Consideration of the Significance of Carbon-14 Discharges from the Nuclear Power Industry." 13th AEC Air Cleaning Conference, 1974.

8. L. H. Brooks et a1., Carbon-14 in the HTGR Fuel Cycle. GA-A13174, 1974.

9. J. W. Snider and S. V. Kaye, "Process Behavior and Environmental Assessment of ${ }^{14 C}$ Releases from an HTGR Fuel Reprocessing Facility." ANS-AICHE Topical Meeting, "Controlling Air-Borne Effluents from Fuel Cycle Plants," Sun Valley, ID, August 1976.

10. J. R. Young et a 1., Information Requirements for Controlled Thermonuclear Reactor Environmental Impact Statements. BNWL-1883, Batte11e, Pacific Northwest Laboratories, Richland, WA, January 1975.

11. B. F. Gore and E. S. Murphy, Current Fusion Power Plant Design Concept. BNWL-2013, Battelle, Pacific Northwest Laboratories, Richland, WA, 1976.

12. Fusion Power Plant, R. G. Mills (Editor), MATT-1050, August 1974.

13. B. Badger et a1., (30 authors), UWMAK-I - A Wiscons in Toroida 1 Fusion Reactor Design. UWFDM-68, Vol. I and II, March 1974, May 1975.

14. B. Badger et a1., (30 authors), UWMAK-II - A Conceptual Tokamak Power Reactor Design. UWFDM-112, Octo ber 1975.

15. An Engineering Design Study of a Reference Theta-Pinch Reactor (RTPR). ANL-LASL Staff, LA-5336, ANL-8019 (Joint Report), Vol. I, March 1974.

16. J. E. Draley, R. A. Krakowski, T. A. Coultas, and V. A. Maroni, An Engineering Design Study of a Reference Theta-Pinch Reactor (RTPR). La-5336, ANL-8019 (Joint Report), Vo1. II, March 1975. 
17. A. P. Fraas, Conceptual Design of the Blanket and Shield Region and Related Systems for a Full-Scale Toroidal Fusion Reactor. ORNL-TM-3096, Oak Ridge National Laboratory, Oak Ridge, TN, May 1973.

18. P. N. Haubenreich and M. Roberts (Editors), ORMAK F/BX: A Tokamak Fusion Test Reactor. ORNL-TM-4634, Oak Ridge Nationa 1 Laboratory, Oak Ridge, TN, June 1974.

19. Central Station Power Generation by Laser Driven Fusion. Compiled by L. A. Booth, LA-4858, Vol. I, An Informal Report, February 1972.

20. S. F. Mughabghab and D. I. Garber, Neutron Cross Sections Vol. I, Resonance Parameters. BNL-325, Brookhaven Nationa 1 Laboratory, NY, 3rd Edition, June 1973.

21. Handbook on Nuclear Activation Cross-Sections. International Atomic Energy Agency, Vienna, 1974.

22. W. E. Alley, R. W. Ge11, and R. M. Lessler, Semi-empirical Neutroninduced Reaction Cross Sections. UCRL-50484, August 1968.

23. J. W. Snider and R. E. Leuze, "An Estimate of the Process Decontamination Factors Required to Meet Federal Effluent Regulations for the Burning of HTGR Fuel Elements." 12th AEC Air Cleaning Conference, 720823, 1972.

24. N. M. Beskorovainyi, V. K. Ivanov, and M. T. Zuev, "Behavior of Carbon in Systems of the Metal-Molten Lithium-Carbon Type." High Purity Metals and Alloys, Fabrication, Properties, and Testing, edited by V. S. Emelyanov and A. I. Evstyukhin, pp. 107-119, 1967.

25. D. L. Smith and K. Natesan, "Influence of Nonmetallic Impurity Elements on the Compatibility of Liquid Lithium with Potential CTR Containment Materials." Nuclear Technology, 22, June 1974.

26. C. E. Wicks and F. E. Block, Thermodynamic Properties of 65 Elements Their Oxides, Halides, Carbides, and Nitrides. Bureau of Mines, But. 605, 1963 .

27. JANAF Thermochemical Tables Second Edition. National Bureau of Standards, NSRDS-NBS 37, 1971.

28. Karl A. Gschneider, Jr., and Nancy Kippenhan, Thermochemistry of the Rare Earth Carbides, Nitrides, and Sulfides for Steelmaking. IS-RIC-5, 1971.

29. A. Glassner, The Thermochemical Properties of the Oxides, Fluorides, and Chlorides to $2500^{\circ} \mathrm{K}$. ANL-5750, Argonne National Laboratory, 1958.

30. Metals Handbook, 8th Ed., Vol. I, Properties and Selection of Metals. Taylor Lyman, Ed., American Society for Metals, Metals Park, Novelty, $\mathrm{OH}, 1961$.

31. C. A. Seitz, W. M. Brodine, and C. B. Klingman, "Apparatus and Procedure to Reduce Impurities in Helium to Less than One Part Per Billion." Journal of Chromatographic Science, 9:29-31, January 1971. 
32. W. J. Knapp and P. E. Lutz, "Performance of Coolant Cleanup System in the Peach Bottom Reactor." Chemical Engineering Progress Symp. Series, Nuclear Engineering - Part XXI, 66:41, 1970.

33. C. Kunz et a1., "C-14 Gaseous Effluent from Pressurized Water Reactors." In Population Exposures, Proc. Eighth Midyear Topical Symposium, Health Physics Soc., Knoxville, TN, October 21-24, 1974.

34. Alternatives for Managing Wastes from Reactors and Post-Fission Operations in the LWR Fuel Cycle. ERDA-76-43, Vol. II, Alternatives for Waste Treatment, 1976. 
A. A. Churm ERDA Chicago Patent Group 9800 S. Cass Avenue Argonne, IL 60439

J. W. Beal

ERDA Div. of Magnetic Fusion Energy Washington, DC 20545

S. 0. Dean

ERDA Div. of Magnetic

Fusion Energy

Washington, DC 20545

E. E. Kintner

ERDA Div. of Magnetic Fusion Energy

Washington, DC 20545

J. M. Williams

ERDA Div. of Magnetic Fusion Energy

Washington, DC 20545

J. N. Grace

ERDA Div. of Magnetic Fusion Energy

Washington, DC 20545

J. Baublitz

ERDA Div. of Magnetic

Fusion Energy

Washington, DC 20545

3 F. E. Coffman

ERDA Div. of Magnetic

Fusion Energy

Washington, DC 20545

J. F. Decker

ERDA Div. of Magnetic

Fusion Energy

Washington, DC 20545

3 K. M. Zwilsky

ERDA Div. of Magnetic

Fusion Energy

Washington, DC 20545

Dr. Philip M. Stone

ERDA Applied Plasma Physics Program

Washington, DC 20545

G. W. Kuswa

ERDA Div. of Laser Fusion

Washington, DC 20545

\section{OFFSITE}

R. Blaunstein

ERDA Div. of Biomedical and Environmental Research Washington, DC 20545

H. M. Busey

ERDA Div. of Military

Application

Washington, DC 20545

M. A. Bell

ERDA Div. of Safety

Standards and Compliance

Washington, DC 20545

27 ERDA Technical Information Center

M. S. Kaminsky

Argonne National Laboratory

9700 S. Cass Avenue

Argonne, IL 60439

V. A. Maroni

Argonne National Laboratory

9700 S. Cass Avenue

Argonne, IL 60439

P. M. Persiani

Argonne National Laboratory

$9700 \mathrm{~S}$. Cass Avenue

Argonne, IL 60439

M. Petrick

Engineering and Technology

Division

Argonne National Laboratory

$9700 \mathrm{~S}$. Cass Avenue

Argonne, IL 60439

W. E. Parkins, Manager

Atomics International

Component Engineering and

Technology Division

North American Rockwell

P. 0. Box 309

Canoga Park, CA 91304

D. Gurinsky

Brookhaven National Laboratory

ERDA Brookhaven Area Office

Upton, NY 11973

H. J. Kouts

Brookhaven National Laboratory

ERDA Brookhaven Area Office

Upton, NY 11973

S. Pearlstein

Brookhaven National Laboratory

ERDA Brookhaven Area Office

Upton, NY 11973

\section{OFFSITE}

J. R. Powe 11

Brookhaven National Laboratory ERDA Brookhaven Area Office Upton, NY 11973

A. J. Impink, Jr. Carnegie Melion University

Pittsburgh, PA 15213

R. A. Gross

Plasma Research Laboratory

236 SW Mudd Bldg.

Columbia University

New York, NY 10027

W. C. Gough

Electric Power Research Inst.

$3412 \mathrm{Hillview}$ Ave.

Palo Alto, CA 94304

G. R. Hopkins

Gulf General Atomic

P.O. Box 1111

San Diego, CA 92112

Zeinab Sabri

Iowa State University

261 Sweeney Hall

Nuclear Engineering Department

Ames, IA 50010

R. Borg

Lawrence Livermore Laboratory

P.0. Box 808

Livermore, CA 94550

T. K. Fowler

Lawrence Livermore Laboratory

P.0. Box 808

Livermore, CA 94550

R. Moir

Lawrence Livermore Laboratory P.0. Box 808

Livermore, CA 94550

A. Carl Haussmann

Lawrence Livermore Laboratory

P.0. Box 808

Livermore, CA 94550

J. Hovingh

Lawrence Livermore Laboratory

P.0. Box 808

Livermore, CA 94550

R. F. Post

Lawrence Livermore Laboratory

P.O. Box 808

Livermore, CA 94550

C. J. Taylor

Lawrence Livermore Laboratory

P. O. Box 808

Livermore, CA 94550 
R. Werner

Lawrence Livermore

Laboratory

P.0. Box 808

Livermore, CA 94550

L. L. Wood

Lawrence Livermore

Laboratory

P.0. Box 808

Livermore, CA 94550

W. Bauer

Division Supervisor

of Physical Research

Sandia Labs Livermore

Livermore, CA 94550

L. Booth

Los Alamos Scientific

Laboratory

CTN Research

P.0. Box 1663

Los Alamos, NM 87544

D. J. Dudziak

Los Alamos Scientific Laboratory

CTN Research

P.0. Box 1663

Los Alamos, NM 87544

D. B. Henderson

Los Alamos Scientific

Laboratory

CTN Research

P.0. Box 1663

Los Alamos, NM 87544

E. L. Kemp

Los Alamos Scientific

Laboratory

CTN Research

P.0. Box 1663

Los Alamos, NM 87544

F. L. Ribe

Los Alamos Scientific

Laboratory

CTN Research

P.0. Box 1663

Los Alamos, NM 87544

L. Stewart

Los Alamos Scientific

Laboratory

CTN Research

P.0. Box 1663

Los Alamos, NM 87544

K. Thomassen

Los Alamos Scientific

Laboratory

CTN Research

P.0. Box 1663

Los Alamos, NM 87544
0. K. Harling

Massachusetts Institute of

Technology

Cambridge, MA 02139

Bruno Coppi

Department of Physics

Massachusetts Institute of

Technology

Cambridge, MA 02139

L. Lidsky

Dept. of Nuclear Engineering

Massachusetts Institute of

Technology

Cambridge, MA 02139

Norm Rasmussen

Dept. of Nuclear Engineering

Massachusetts Institute of

Technology

Cambridge, MA 02139

David Rose

Massachusetts Institute of

Technology

Cambridge, MA 02139

R. E. Stickney

Mechanical Engineering

Massachusetts Institute of

Technology

Cambridge, MA 02139

J. J. Reinmann

NASA - Lewis Research Center

2100 Bookpark Rd.

Cleveland, $\mathrm{OH} 44135$

Vincent Arp

National Bureau of Standards

Cryogenics Division

Boulder, CO 80302

J. F. Clarke

Oak Ridge National

Laboratory

P.0. Box Y

Oak Ridge, TN 37830

A. P. Fraas

Oak Ridge National

Laboratory

P.0. Box Y

Oak Ridge, TN 37830

J. Rand McNally, Jr.

Oak Ridge National

Laboratory

P.0. Box Y

Oak Ridge, TN 37830

D. Steiner

Oak Ridge National

Laboratory

P.0. Box $Y$

Oak Ridge, TN 37830

\section{OFFSITE}

J. $5 \cot t$

Oak Ridge National Laboratory

P. 0. Box $X$

Oak Ridge, TN 37830

J. Banford

Physics International

2700 Merced St.

San Leandro, CA 94577

R. A. Huse

Public Service Electric

and Gas Co.

80 Park Place

Newark, NJ 07101

M. Gottlieb

Princeton University, PPPL

P.0. Box 451

Princeton, NJ 08540

R. G. Mills

Princeton University

P.0. Box 451

Princeton, NJ 08540

E. C. Tanner

Princeton University

P.0. Box 451

Princeton, NJ 08540

H. Perkins

Dept. of Chemistry

Princeton University

Princeton, NJ 06540

R. E. Gold

303 Sayre Hall

Forrestal Campus

P.0. Box 451

Princeton, NJ 06540

M. Kristiansen

Texas Tech. University

Lubbock, TX 79409

A. F. Haught

United Aircraft Research Lab.

United Aircraft Corporation

East Hartford, CT 06108

L. Levine

U.S. Naval Research Laboratory Washington, DC 20390

C. Z. Serpan, Jr

U.S. Naval Research Laboratory washington, DC 20390

Francis Chen

University of California

Electronics Research

Laboratory

College of Engineering

Berkeley, CA 94720 
A. J. Lichtenberg

University of California

Electronics Research

Laboratory

College of Engineering

Berkeley, CA 94720

Dave Okrent

U.C.L.A.

Los Angeles, CA 90024

C. D. Hendricks

University of Illinois

Nuclear Engineering

Laboratory

Urbana, IL 61801

G. H. Miley

University of Illinois

Nuclear Engineering

Laboratory

Urbana, IL 61801

Terry Kammash

University of Michigan

Nuclear Engineering

Department

Ann Arbor, MI 48105

Dean Abrahamson

University of Minnesota

School of Public

Affairs

Social Science

Building/309

Minneapolis, MN 55455

W. G. Davey

University of Texas

Department of Physics

Austin, TX 78712

E. Linn Draper, Jr. University of Texas Department of Physics Austin, TX 78712

W. E. Drummond University of Texas

Department of Physics

Austin, TX 78712

Abraham Hertzberg

University of Washington

Aerospace Research

Laboratory

316 Guggenheim

Seattle, WA 98105

A. L. Babb

University of Washington

Nuclear Engineering

Department

Seattle, WA 98105
R. Conn

University of Wisconsin

Nuclear Engineering

Department

Madison, WI 53706

G. L. Kulcinski

University of Wisconsin

Nuclear Engineering

Department

Madison, WI 53706

C. W. Maynard

University of Wisconsin

Nuclear Engineering

Department

Madison, WI 53706

D. Lichtman

Department of Physics

University of Wisconsin

Milwaukee, WE 53201

E. E. Donaldson

Washington State University

Deparment of Physics

Pullman, WA 99163

D. D. Mahlum

Division of Biomedical

and Environmental Research

Washington, DC 20545

J. V. Vanston

Engineering Science

Building

University of Texas

Austin, TX 78712

Leslie S. Ramsey

450 North 5 th Street

Indiana, PA 15701 
ERDA Richland Operations Office

W. A. Burns

Atlantic Richfield Hanford Company

J. D. Kaser

Hanford Engineering

Development Labs

D. G. Doran

H. H. Yoshikawa

Battelle-Northwest

D. T. Aase

G. S. Allison

T. W. Ambrose

D. G. Atteridge

5 D. A. Baker

J. L. Bates

M. A. Bayne

E. R. Bradley

J. L. Brimhall

R. L. Brodzinski

R. J. Brouns

L. R. Bunnell

5 L. L. Burger

S. H. Bush

5 N. E. Carter

T. D. Chikalla

R. G. Clark

T. L. Criswell

S. D. Dahigren

M. T. Dana

D. F. Deonigi

R. L. Dillon

D. A. Dingee

P. J. Dionne

B. H. Duarre

J. W. Finnigan

5 J. C. Fox

J. J. Fuquay

J. E. Garnier

A. A. Garrett

R. D. Gastil

B. F. Gore

W. J. Gray

M. S. Hanson

J. N. Hartley

A. J. Haverfield

J. H. Jarrett

J. P. Jenquin

A. B. Johnson, Jr.

R. H. Jones

T. J. Kabele
Battelle-Northwest - Continued

W. S. Kelly

H. E. Kissinger

D. A. Kottwitz

N. Laegried

B. R. Leonard, Jr

D. L. Lessor

H. B. Liemohn

R. C. Liikala

M. A. McKinnon

R. F. Maness

5 R. P. Marshall

E. S. Murphy

R. D. Nelson

D. F. Newman

R. E. Nightingale

D. E. Olesen

5 L. T. Pedersen

R. T. Perry

D. R. Pratt

L. A. Rancitelli

J. F. Remark

U. S. Renné

R. E. Rhoads

W. O. Richmond

W. F. Sandusky

R. D. Scheele

5 L. C. Schmid

iv. M. Sherer

E. P. Simonen

R. I. Smith

J. K. Soldat

C. W. Stewart

K. B. Stewart

5 R. W. Stewart

J. A. Strand

D. L. Styris

A. M. Sutey

V. L. Teofilo

G. L. Tingey

M. T. Thomas

R. C. Thompson

L. H. Toburen

T. J. Trapp

H. H. Van Tuyl

R. Wang

R. E. Westerman

L. D. Williams

J. R. Young

M. G. Zimmerman

1 Technica? Publications (BH)

5 Technical Information 